\title{
Application of Marketing Mix Elements to Improve Customer Satisfaction of Main Library, University of Colombo
}

\author{
S.S. Johoran ${ }^{1}$
}

\begin{abstract}
This research study focuses on the application of marketing mix elements mainly Product, Price, Place and Promotion to improve user satisfaction of a library. Libraries need to adopt marketing mix strategies in order to retain existing users and to attract more users to the library. The main objective of this study was to identify which element among product, price, place and promotion mostly affect library user satisfaction. This study involved 364 library users who were selected using Stratified Random Sampling technique. The sample size was determined by using Krejcie \& Morgan's "table for determining sample size of a given population". SelfAdministrated Questionnaires were used for data collection from the sample. Data analysis and presentation were done using SPSS and Microsoft Excel 2013 software packages. The major objective of this study was tested using stepwise multiple regression analysis and the specific objectives were tested using Pearson Correlation Coefficient. The result depicts that, there is a positive linear correlation between these four variables and library user satisfaction. There is a strong positive relationship between Product \& Promotion elements with the library user satisfaction, when compared with other two elements. The result indicates that Promotion element had a significant impact on library user satisfaction. Library can focus more on promotion element and consider more on effective promotion methods in order to improve library user satisfaction. Survey results indicate that, $26 \%$ of the users prefer receiving emails regarding library services mostly as a promotional method. $41 \%$ of the respondents have stated that, library does not use effective promotion methods. Library can interact with their users through social networking, especially via Facebook. And most importantly a good word of mouth regarding the library may increase the positive image of the library and it would result in gaining more users. This research study is significant since the library administration can identify and develop favourable marketing strategies to improve user satisfaction by considering the marketing mix elements; product, price, place and especially promotion.
\end{abstract}

Keywords: Library user satisfaction, Place, Price, Product, Promotion

\section{Introduction}

The core objective of a library is to furnish its users with accurate information at the right time and place in the right manner. A university library needs to adopt marketing

\footnotetext{
${ }^{1}$ Assistant Librarian, Main Library, University of Colombo, Sri Lanka, E-mail: shabnam@lib.cmb.ac.lk, (D) https://orcid.org/0000-0003-2634-1682
} 
concepts, in order to survive and exceed other opponent organizations, to retain existing library users and to attract new users to the library.

In order to perform marketing functions, marketing mix is used as a strategy. The 4'P's of marketing mix includes four elements; product, price, place and promotion (Perreault \& McCarthy, 2002). These marketing mix elements emphasize its focus on the customer.

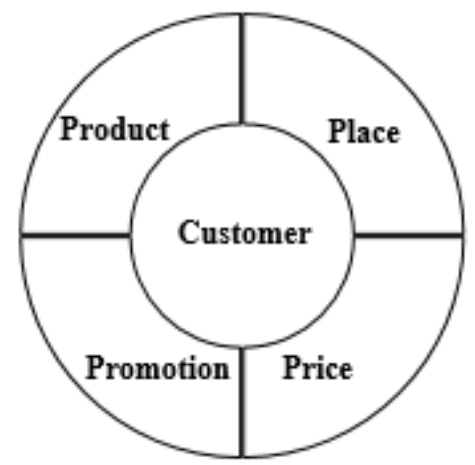

Figure 1: Four "P”s of marketing mix (Perreault \& McCarthy, 2002: p. 48)

In addition, the service marketing mix or the 7 "P"s include further three elements; physical evidence, process and people. According to Dhiman and Sharma (2009), "people element concerns the staff who occupies the key position in influencing customer's perceptions of product quality because of the simultaneity of production and consumption in services in the continuing education"(p. 458). They had stated that, "the process element focuses on procedures, mechanism and flow of activities by which a service is acquired. Process decisions radically affect how a service is delivered to customers" (Dhiman \& Sharma, 2009, p. 458). Dhiman and Sharma (2009), explained "physical evidence element focuses on the environment in which the service is delivered and any tangible goods that facilitate the performance and communication of the service" (p. 458-459).

Physical evidence, process and people elements of the service marketing mix can be combined with the "Product" element of 4 "P" $\mathrm{s}$ of marketing mix. According to Dhiman and Sharma (2009) "it is possible to discuss people, physical evidence and process within the original-Ps framework. For an example, people can be considered part of the product offering" (p.458). Therefore, the researcher has focused more on 4 "P" s marketing mix model.

University libraries can adopt these marketing mix elements to increase consumer satisfaction. In the context of a university library, consumers are the library users and the marketing mix elements can be utilized / applied to increase the customer satisfaction.

Product element considers on producing goods or services which fulfils the needs and wants of their customers (Perreault \& McCarthy, 2002). Services provided by the 
library are considered as library's products. It can be in tangible or intangible forms. The services offered by the library of the University of Colombo are: Reference services, Lending services, Online Public Access Catalogue (OPAC), Document supply service, Laptop lending service, Wi-Fi service, Learning commons, Photocopying service, Inter library loan service (ILL), Resource center for the visually impaired, etc. These are some of the library products which can be marketed effectively.

Place element emphasizes all the activities conducted in providing the right product to their customers at the right time (Perreault \& McCarthy, 2002). It represents the channel of distribution an organization uses to convey its products to the customer. Distribution in the milieu of a library focuses on three main aspects such as the time period in which information is provided, the location where the service is provided and the way of distribution of the service. The library of University of Colombo has enabled the Online Public Access Catalogue via library website as well as by placing computers at each collection to help the users to find the availability of books/materials they need within the library without any delay. The library is located in the center of service providing faculties namely arts, law, management, education and science, which makes it more convenient for its users to access. Librarians answer user inquiries by face to face interaction or using emails in a timely manner. These factors can be considered under place element when considering the level of user satisfaction.

Promotion element is concerned with the activities involved in informing the customers and others about the right product and persuades them to use it (Perreault \& McCarthy, 2002). Library users must be acquainted with information about the services offered to them by the library. Social networking, workshops, and highperformance websites, are some of the promotional marketing tools which can be used in libraries.

The amount a consumer is willing to offer for his product is considered as the price (Perreault \& McCarthy, 2002). Price of library products include library fines, library membership fees, entrance fee for special collections, photocopy charges, lost book charges, subscription charges etc. Garusing-Arachchige (2002) has explained that "by using the subscription strategy, library users may pay a regular amount of fee on a discount rate or not for the service rendered. For example, the user can obtain the membership for bulletin boards, SDI services, etc. under this method" (p.17).

\section{Significance of the study}

This study has a significant effect on the institution since the administrators can develop favorable marketing strategies considering these marketing mix elements in order to increase Library user satisfaction. The findings of this research will be helpful to other Sri Lankan University libraries as well and can be used to increase library user satisfaction and the usage of their libraries. 


\section{Problem statement}

The main research issue of this study is "what are the marketing mix elements that impact library user satisfaction".

If these prominent marketing mix elements were not addressed precisely, there would be a hindrance to the satisfaction of the library users. Therefore, to solve this issue it is important to identify what marketing mix element has the most impact on library user satisfaction.

Information specialists and some librarians have an opinion that library resources are being underutilized due to lack of know how in using them and also due to poor marketing practices (Garusing-Arachchige, 2002). As the researcher has observed, most of the library users are unaware of the available resources and how to utilize them effectively, researcher identified this issue while interacting with the library users who come in search of help in finding relevant library materials they need. Library user satisfaction can be increased by adapting the marketing mix elements which can be practiced in a library (Garusing-Arachchige, 2002).

\section{Objectives of the study}

\section{Major objective}

The major objective of this research is to identify which element among Product, Price, Place and Promotion that may mostly affect library user satisfaction, with special reference to the Main Library of University of Colombo.

\section{Specific objectives}

1. To find out the relationship between "Product" element and library user satisfaction.

2. To find out the impact of "Price" element on library user satisfaction.

3. To find out whether "Place" element impact on library user satisfaction.

4. To identify the impact of "Promotion" element, on library user satisfaction.

\section{Conceptual Framework}

The following figure indicates the conceptual framework of the research.

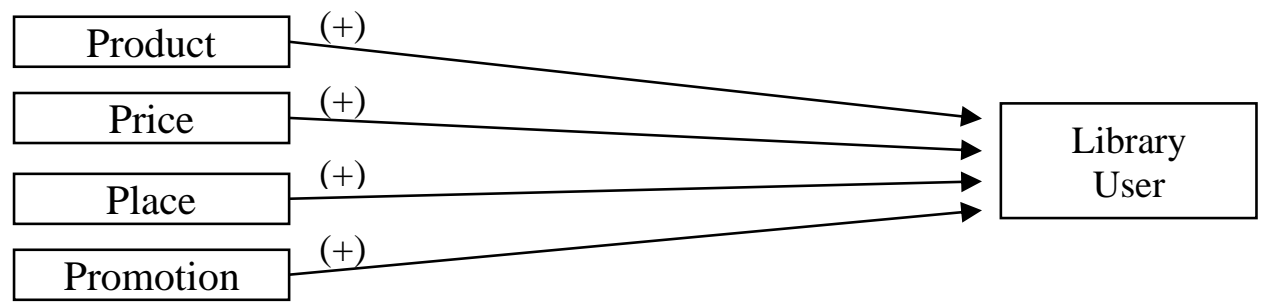

Figure 2: Conceptual Framework 
Dependent variable: - Library user satisfaction

Independent variables: - Product, Price, Place and Promotion

The following hypotheses were derived in the context of main library, University of Colombo.

Hypothesis 01

$\mathrm{H}_{0}$ :- There isn't a relationship between product element and library user satisfaction.

$\mathrm{H}_{1}$ :- There is a relationship between product element and library user satisfaction.

Hypothesis 02

$\mathrm{H}_{0:-}$ - The price element has no effect on library user satisfaction.

$\mathrm{H}_{1:-}$ The price element has an effect on library user satisfaction.

Hypothesis 03

$\mathrm{H}_{0:-}$ - The place element has no impact on library user satisfaction.

$\mathrm{H}_{1:-}$ The place element has an impact on library user satisfaction.

Hypothesis 04

$\mathrm{H}_{0:-}$ There isn't a relationship between promotion element and library user satisfaction.

$\mathrm{H}_{1:-}$ - There is a relationship between promotion element and library user satisfaction.

\section{Literature Review}

Jamaludin et al. (2015) stated "libraries need to make a greater effort to improve their services in terms of quality as much as in forms of delivery, in order to convince people to use them, instead of turning to alternative information providers such as the search engine in the Internet" (Garoufallou et al., 2013 as cited by Jamaludin et al., 2015, p.74).

The new information dominant society has created an environment in which libraries have to change their role and adopt new trends in this technological environment in order to survive. According to Jamaludin (2015) "the adoption of marketing could assist libraries in their struggle to survive in the emerging and increasingly competitive information environment" (Rowley, 1995 as cited by Jamaludin et al., 2015, p.74).

Garoufallou et al. (2013) stated "Information specialists began to consider that certain aspects of marketing might be a significant mean by which to improve library services" (Koontz et al., 2006, p. 225 as cited by Garoufallou et al., 2013, p.633). According to Bennett (1997) "the product and/or services tailored for maximum customer benefit, priced according to the buyer's ability to afford the product, made available for the customer to buy (place) and promoted in order that potential buyers knew as much as required about the product on offer" (Bennett, 1997, p.151). Ewers and Austen (2004) identified "applied strategies and operations of the marketing mix 
model, at the Queensland University of Technology Library in Australia, highlighting the importance of staff as a major factor for services provision. They argued that librarians will compete for better customer service and demonstrate their creativity in finding ways, not only to increase funding, but also to improve the quality of library services by applying the marketing concepts in service operations" (Ewers \& Austen, 2004, p. 10 as cited by Garoufallou et al., 2013, p.634).

In 1990, Seddon stated in her study that, "if marketing methods are applied appropriately, it can make a vital contribution to library and information work" (p.35). A library can attract and retain more library users by adopting marketing strategies. Marketing will help to increase the user awareness on library services and resources.

For generations, libraries have played a major role in providing information sources to the community. Present marketing strategies need to be reviewed in order to serve the potential and existing users. Garoufallou (2013) stated "librarians realized that they should view their users as customers, identify and understand their needs and demands, then adopt marketing strategies to meet those needs" (Rowley, 2000; Ewers and Austen, 2004 as cited by Garoufallou et al., 2013, p.633). In 2007, Vrana \& Barbaric mentioned in their study that, "as a result of adopting marketing strategies, for library customers it could mean more appropriate services that meet their needs better; for library staff a better understanding of their roles in achieving organizational and personal goals and for libraries it could mean survival" (p.436).Perreault \& McCarthy (2012) defined Promotion as "communicating information between seller and potential buyer or others in the channel to influence attitudes and behavior. The marketing manager's main promotion job is to tell target customers that the right Product is available at the right place at the right price" (Perreault \& McCarthy, 2002, p.392). In the context of a library the marketing managers are considered to be the library staff. They should communicate the right information to the right customer at the right time. According to Perreault \& McCarthy (2012), there are three basic objectives of promotion: informing, persuading and reminding the target customers about the organization and its marketing mix. A library could fulfill these three objectives by informing its users in a timely manner about the current services they provide and new arrivals of books /journals. Persuading its users to use their products and services and reminding them frequently about available resources via emails, SMS services, social networking, etc.

\section{Methodology}

The population of the research was the users of the Main Library, University of Colombo. The population was heterogeneous and it composed of 7988 library users. The researcher considered user categories namely undergraduates, postgraduates, academic staff members, administrative staff members and non-academic staff members. The heterogeneous population was divided into homogeneous sub groups according to these user categories. Stratified random sampling method was used to draw the sample. The sample size was determined by using Krejcie \& Morgan's "table for determining sample size of a given population" (Krejcie \& Morgan, 1970) 
and the sample size was 364 library users. The main data collection method was selfadministrated questionnaires. Primary data was collected by distributing structured questionnaires among the sample. Secondary data was collected through analyzing research articles of previous studies. In order to measure the responses, researcher has used a six-point Likert scale in the questionnaire. The major objective of the study was tested using Stepwise Multiple Regression analysis and specific objectives were tested using Pearson Correlation Coefficient. Data was analyzed and presented using SPSS and Microsoft Excel 2013 software packages and statistical parameters were considered.

\section{Results and Discussion}

To test the specific objectives, Pearson correlation coefficient was used. If Pearson correlation coefficient is greater than 0.5 , then there is a strong positive relationship and if it is less than 0.5 , then there is a positive, but not a strong relationship.

For this study ' $\mathrm{P}$ ' value is used to get a conclusion on the hypothesis. The confidence level of this study is $99 \%$. The level of precision is $1 \%$. Therefore, the critical $\mathrm{P}$ value is 0.01 . If the calculated ' $\mathrm{P}$ ' value is less than critical ' $\mathrm{P}$ ' value, then the null hypothesis $\left(\mathrm{H}_{0}\right)$ is rejected. Correlation is significant at 0.01 level (2-tailed).

\section{Test Statistics of Product Element}

$\begin{array}{lll}\text { Pearson Correlation } & =.531^{* *} \\ \text { Significant level }(2 \text {-tailed }) & =.000 & \\ \text { Calculated 'P' value }(0.000)<\text { Critical 'P' value }(0.01) & \text { then, reject } \mathrm{H}_{0}\end{array}$

The significant level is (calculated ' $\mathrm{P}$ ' value) 0.000 ; which is less than critical ' $\mathrm{P}$ ' value 0.01 . Therefore, the null hypothesis $\left(\mathrm{H}_{0}\right)$ is rejected. And accept the alternative hypothesis $\left(\mathrm{H}_{1}\right)$; which is "There is a relationship between product element and library user satisfaction".

The Pearson correlation coefficient for the product element is 0.531 ; which is above 0.5. Therefore, there is a strong positive correlation between product element and library user satisfaction. The slope of the linear trend line is positive in the following scatter plot, which indicates that there is a strong positive relationship between these two variables. 


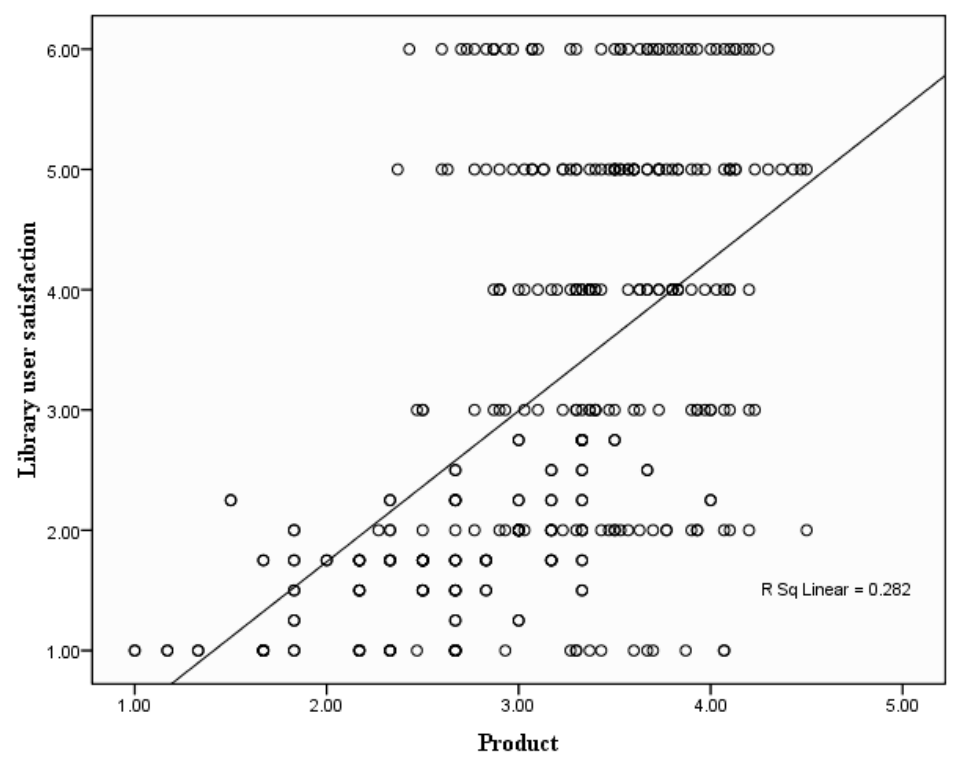

Figure 3: Scatter plot of Product element with Library user satisfaction

Test Statistics of Price Element

Pearson Correlation $\quad=.380^{* * *}$

Significant level (2-tailed) $\quad=.000$

Calculated 'P' value $(0.000)<$ Critical 'P' value (0.01) then, reject $\mathrm{H}_{0}$

The significant level is (calculated ' $\mathrm{P}$ ' value) 0.000 ; which is less than critical ' $\mathrm{P}$ ' value 0.01 . Therefore, the null hypothesis $\left(\mathrm{H}_{0}\right)$ is rejected. And accept the alternative hypothesis $\left(\mathrm{H}_{1}\right)$; which is "The price element that has an effect on library user satisfaction."

The Pearson correlation coefficient for the price element is 0.380 ; which is less than 0.5 . Therefore, there is a positive but not strong correlation between price element and library user satisfaction. The slope of the linear trend line is positive in the following scatter plot, which indicates that there is a positive but not strong relationship between these two variables. 


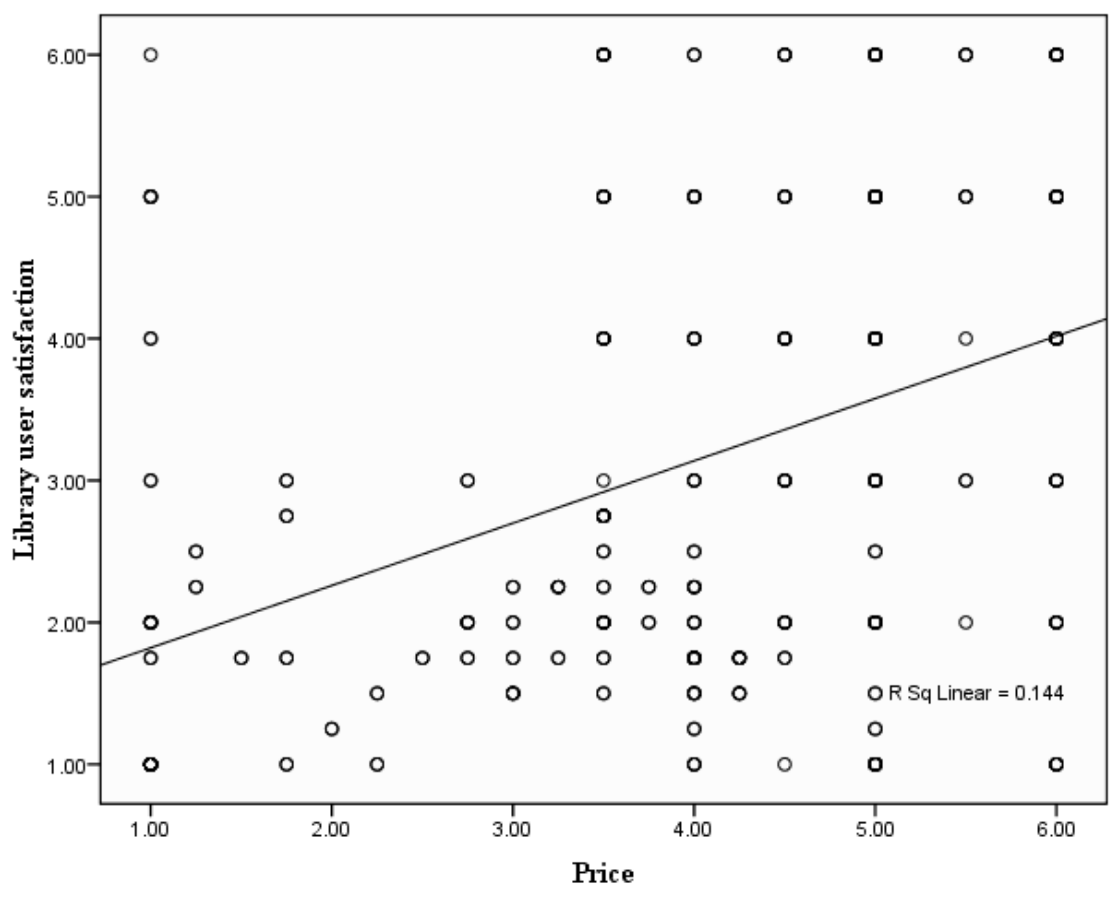

Figure 4: Scatter plot of Price element with Library user satisfaction

Test Statistics of Place Element

Pearson Correlation $\quad=.357^{* *}$

Significant level (2-tailed) $\quad=.000$

Calculated 'P' value $(0.000)<$ Critical 'P' value (0.01) then, reject $\mathrm{H}_{0}$

The significant level is (calculated ' $\mathrm{P}$ ' value) 0.000 ; which is less than critical ' $\mathrm{P}$ ' value 0.01 . Therefore, the null hypothesis $\left(\mathrm{H}_{0}\right)$ is rejected. And accept the alternative hypothesis $\left(\mathrm{H}_{1}\right)$; which is "The place element has an impact on library user satisfaction".

The Pearson correlation coefficient for the place element is 0.357 ; which is less than 0.5 . Therefore, there is a positive but not strong correlation between place element and library user satisfaction. The slope of the linear trend line is positive in the following scatter plot, which indicates that there is a positive but not strong relationship between these two variables. 


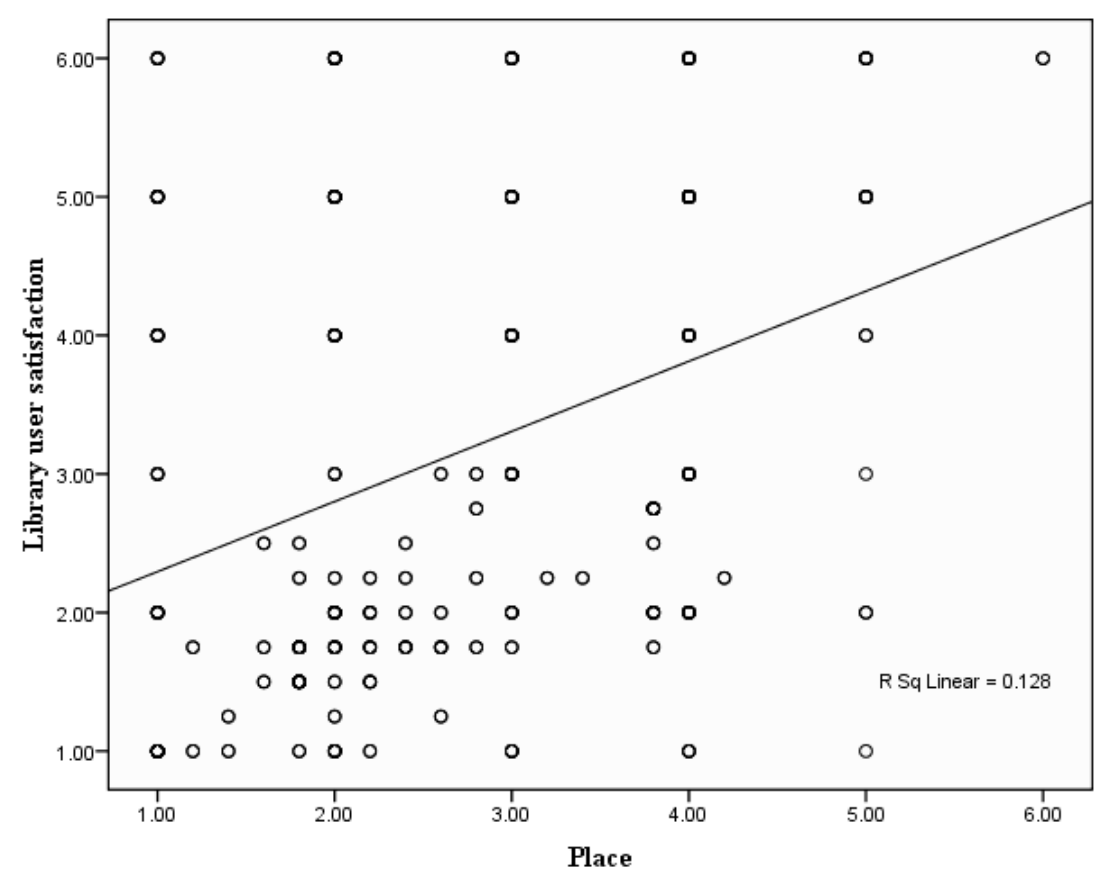

Figure 5: Scatter plot of Place element with Library user satisfaction

Test Statistics of Promotion Element

Pearson Correlation $\quad=.557^{* * *}$

Significant level (2-tailed) $\quad=.000$

Calculated 'P' value $(0.000)<$ Critical 'P' value $(0.01) \quad$ then, reject $\mathrm{H}_{0}$

The significant level is (calculated ' $\mathrm{P}$ ' value) 0.000 ; which is less than critical ' $\mathrm{P}$ ' value 0.01 . Therefore, the null hypothesis $\left(\mathrm{H}_{0}\right)$ is rejected. And accept the alternative hypothesis $\left(\mathrm{H}_{1}\right)$; which is "There is a relationship between promotion element and library user satisfaction".

The Pearson correlation coefficient for the promotion element is 0.557 ; which is higher than 0.5 . Therefore, there is a strong positive correlation between promotion element and library user satisfaction. The slope of the linear trend line is positive in the following scatter plot, which indicates that there is a strong positive relationship between these two variables. 


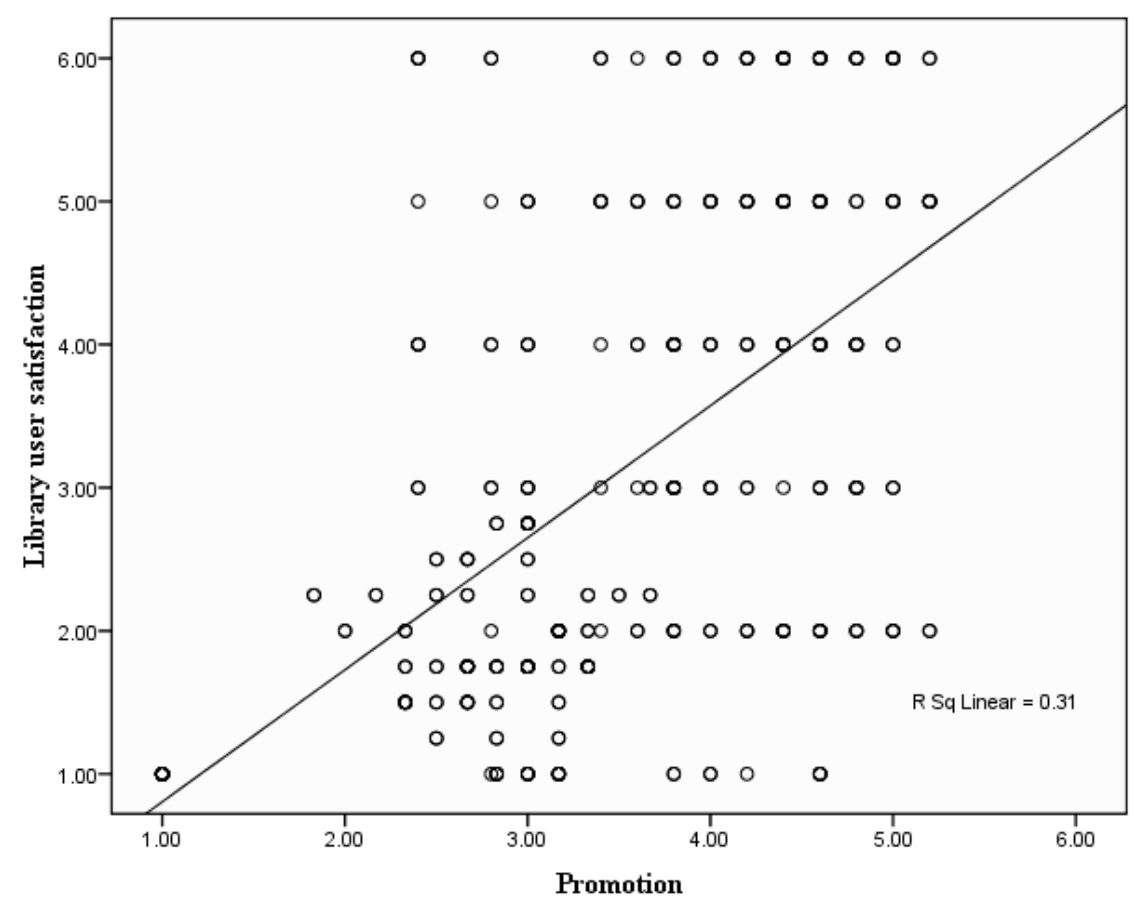

Figure 6: Scatter plot of Promotion element with Library user satisfaction

The Pearson correlation coefficients of product and promotion elements are higher than 0.5 , which indicates that those two elements have a strong positive relationship with library user satisfaction. Library can consider more on these two elements in order to improve library user satisfaction.

\section{The Most Important Element that Affects Library User Satisfaction}

The major objective of this research was to identify which element among product, price, place and promotion that may mostly affect library user satisfaction. In order to cover this major objective multiple regression analysis was considered. The stepwise regression was applied to identify the most important variable in the model. The result of regression of the four independent variables against the dependent variable library user satisfaction is shown in the table below. It shows the aggregate impact of the four variables on the library user satisfaction. 
Table 2. Model summary of regressing four predictors on dependent variable Model Summary

\begin{tabular}{|c|c|c|c|c|}
\hline Model & $\mathrm{R}$ & R Square & Adjusted R Square & $\begin{array}{c}\text { Std. Error of the } \\
\text { Estimate }\end{array}$ \\
\hline 1 & $.609^{\mathrm{a}}$ & .371 & .364 & 1.32626 \\
\hline
\end{tabular}

a. Predictors: (Constant), Promotion, Place, Price, Product

The square of the multiple $\mathrm{R}$ is 0.371 , which indicates that the $37 \%$ of variance in library user satisfaction is explained by four variables jointly. The table below shows the model summary after applying the stepwise multiple regression procedure. All the variables are significant at $99 \%$ level of significance.

Table 3. Model Summary of stepwise multiple regression analysis

Model Summary

\begin{tabular}{|c|c|c|c|c|}
\hline Model & R & R Square & Adjusted R Square & $\begin{array}{c}\text { Std. Error of the } \\
\text { Estimate }\end{array}$ \\
\hline 1 & $.557^{\mathrm{a}}$ & .310 & .308 & 1.38284 \\
2 & $.592^{\mathrm{b}}$ & .350 & .347 & 1.34412 \\
3 & $.601^{\mathrm{c}}$ & .361 & .356 & 1.33463 \\
4 & $.609^{\mathrm{d}}$ & .371 & .364 & 1.32626 \\
\hline
\end{tabular}

a. Predictors: (Constant), Promotion

b. Predictors: (Constant), Promotion, Product

c. Predictors: (Constant), Promotion, Product, Place

d. Predictors: (Constant), Promotion, Product, Place, Price

According to the above stepwise multiple regression analysis table, the Promotion variable has the highest contribution to the total explanatory power of the regression model with a contribution of $0.310 \mathrm{R}^{2}$ value. This approximately explains $31 \%$ from the total explanatory power. It concludes that the most prominent variable which influences library user satisfaction is 'promotion' variable.

In order to identify the fourth specific objective, which is the impact of promotion element on library user satisfaction, the respondents were asked how they prefer to get information about library services. This question was asked as a measurement of 
operationalization of the promotion variable. The following figure illustrates the results.

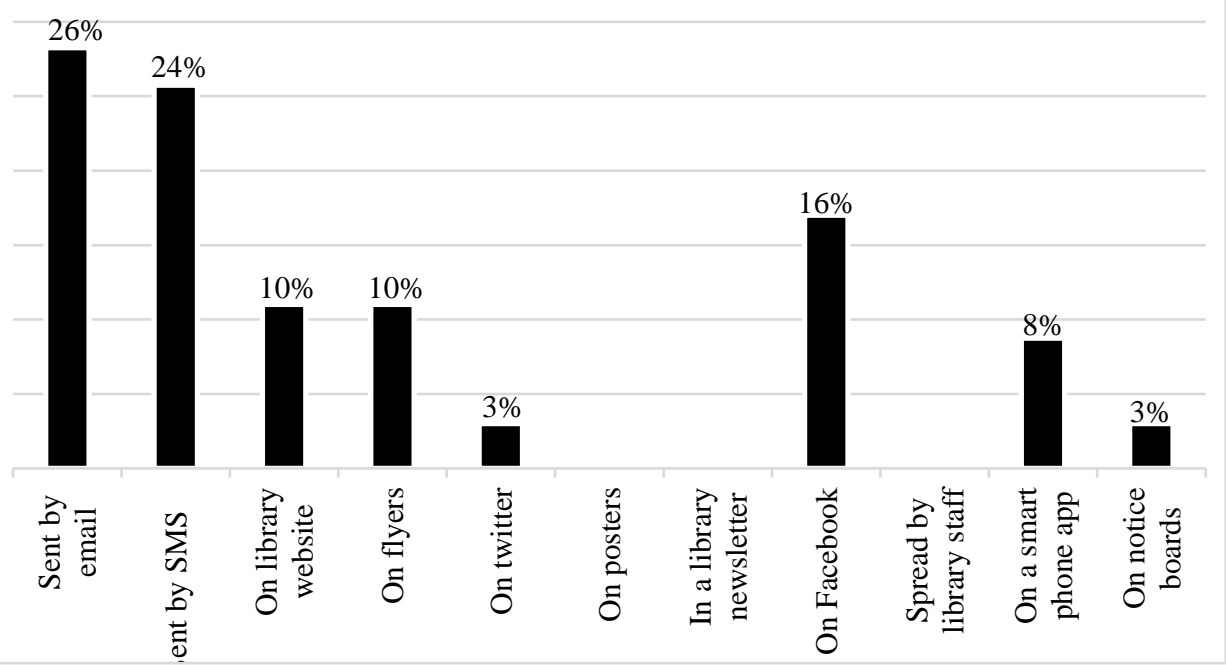

\section{Figure 7: How users prefer to get information about library services}

As per the above survey data, most of the users prefer to get information about library services via email. The three most preferred promotion methods are e-mails, SMS and Facebook. Library staff can consider promoting their services by giving priority for these three promotional ways. The result indicates that users do not prefer to get information about library services via posters, newsletters and through library staff. This may be due to those methods are not being used or users are unaware of such promotion methods used by the library.

In operationalization of the promotion variable, as a measurement, library users were asked whether the library uses effective promotion methods to advertise its services and events. The following figure depicts the results.

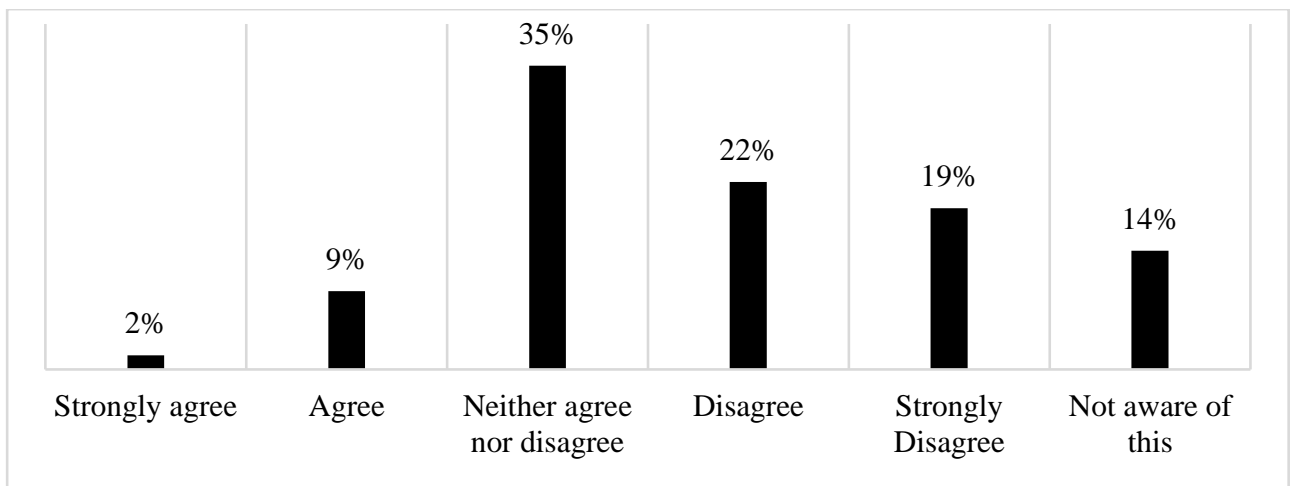

Figure 8: User agreement on the effectiveness of library's promotional methods 
The above survey data depicts that $22 \%$ disagree and $19 \%$ strongly disagree, which indicates altogether $41 \%$ of the users have disagreed with the statement: "Library uses effective promotion methods to advertise its services and events". $14 \%$ of users are unaware of the promotional methods used by the library. Only $11 \%$ of the users have agreed with the above statement. Based on the above survey data, the library can consider more on effective promotional methods to improve its user satisfaction.

In operationalization of the product variable, as a measurement, users were asked about their satisfaction on various library collections and sections. The following figure illustrates the results.

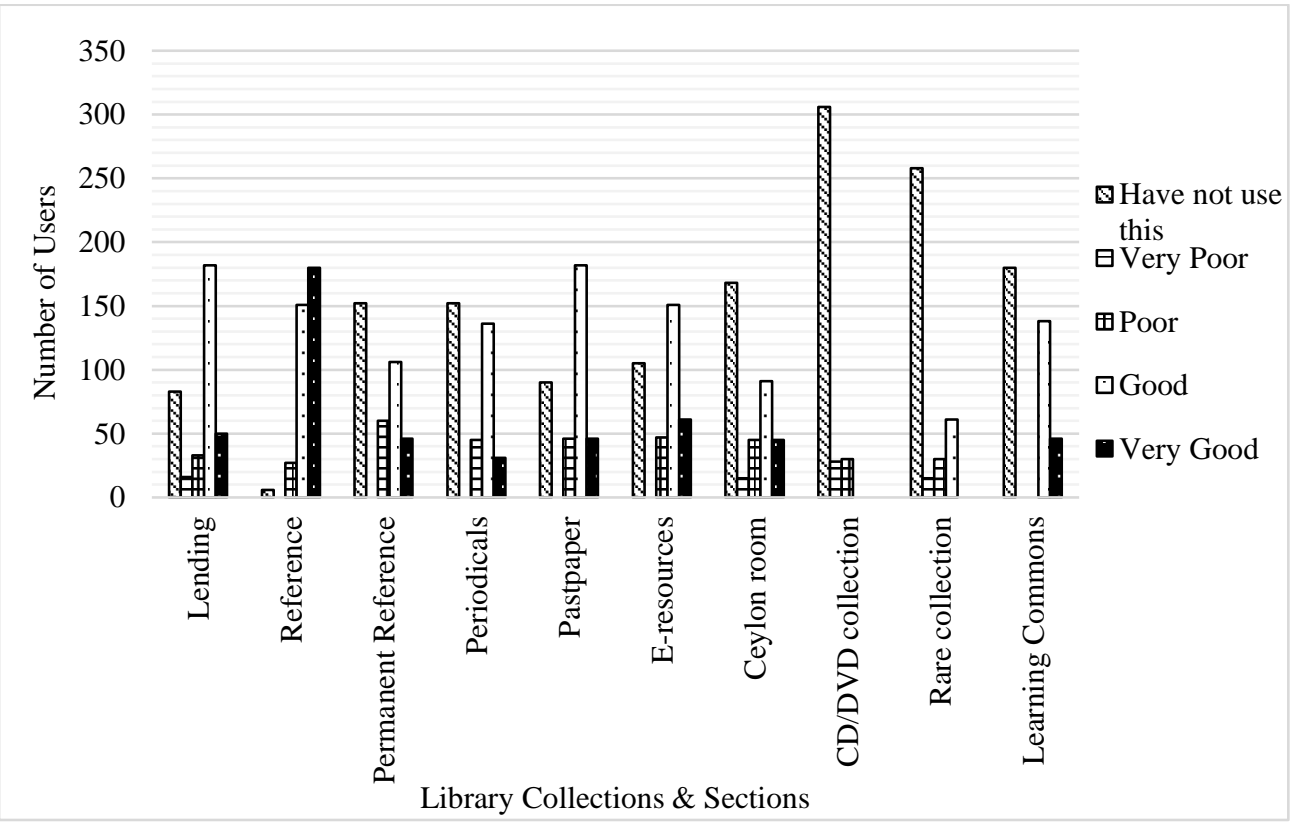

Figure 9: User experience with the collections \& sections at the main library

This graph clearly depicts that more focus is needed in developing the CD/DVD collection. Approximately, 300 library users have stated that they have not used the CD/DVD collection followed by 260 users who are unaware of the rare collection maintained by the library. The library can consider more on collection development since there is a strong positive relationship between product element and library user satisfaction.

The following graph illustrates the users experience with the services provided by the library. 


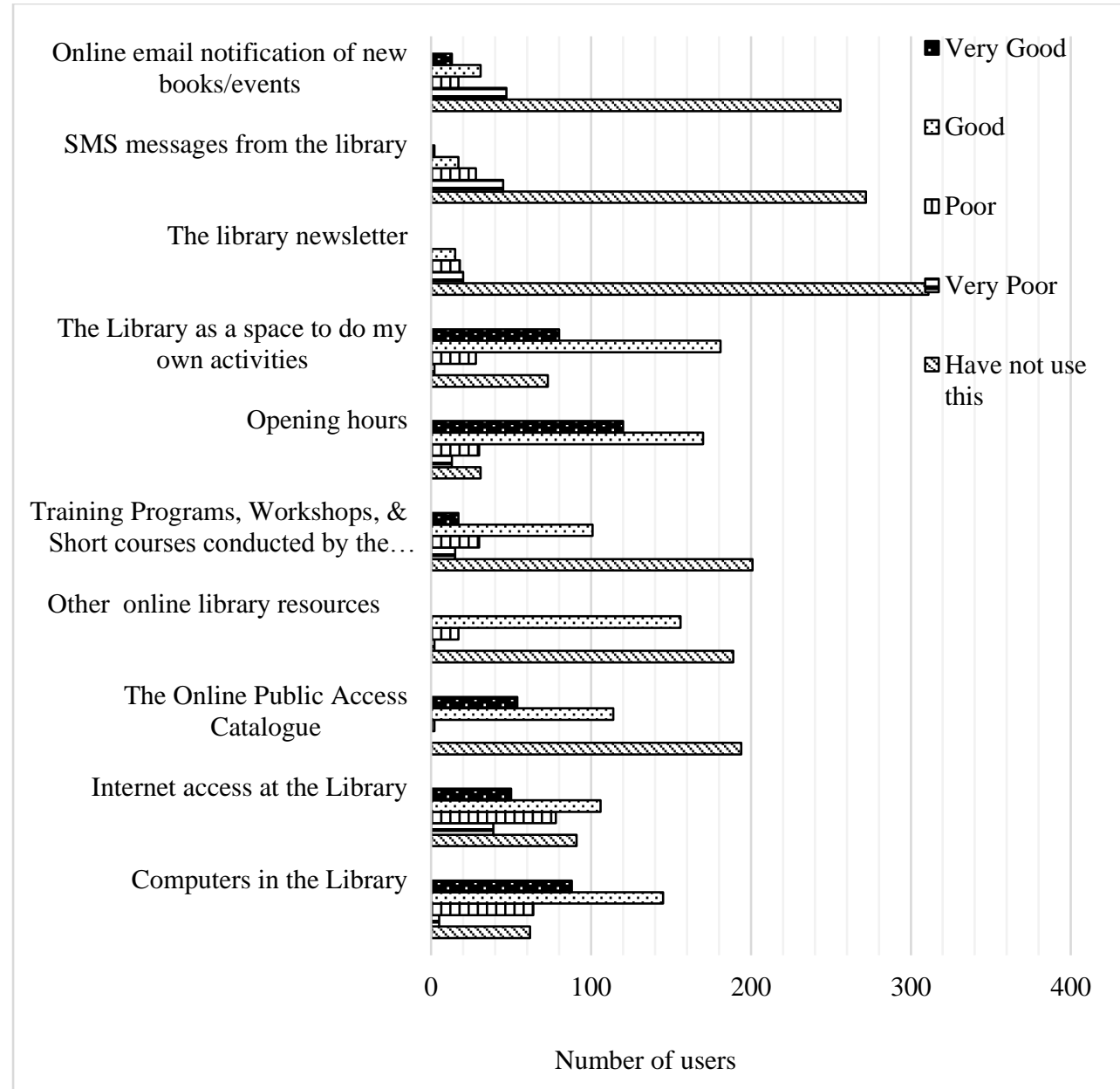

Figure 10: User experience with the services provided by the main library

As per the above survey data, the researcher has identified that most of the library users have not used the services provided by the library.

Giving more consideration on collection development and increasing the awareness of library services, will in return help to elevate library users' satisfaction. If the users are more satisfied with their library, they tend to retain and take maximum usage of the resources provided by the library.

In the context of a library, the place element of the marketing mix emphasizes providing the right product to the user at the right time. Library resources should be available for its users, when they need them and it should be provided without any delay. In order to identify the user agreement on place element, users were asked whether they can easily find the resources which they search for within the library. The following figure illustrates the results. 


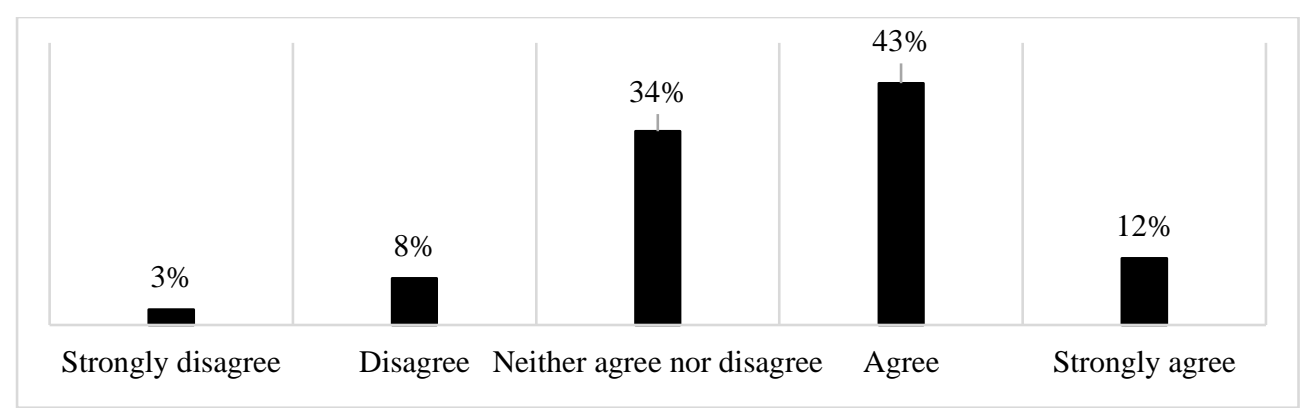

Figure 11: User agreement with the location of library resources

The above survey data portrays that, $43 \%$ agree and $12 \%$ strongly agree, which indicates altogether about $55 \%$ of users agree that they can easily find the library resources they need, within the library.

\section{Recommendation}

Library should focus on their marketing methods by identifying who needs what of the services they provide and what is the most effective way to communicate with them. Nowadays everyone has a smartphone and it is the easiest way to reach someone. The survey data depicts that most of the users prefer to receive details about library services and events via emails, SMS and Facebook. Emails can be sent for users reminding their due dates, about workshops/special events organized by the library, new arrivals, how to use the library and its services etc.

As a promotional marketing tool social networking can be used. Facebook is a very popular social network app in our smartphones. There is a need for an attractive Facebook page for the library. By tapping the creative side of the staff, a social media marketing plan can be implemented via Facebook. The library could consider promoting its services and interacting with its users via Facebook as well. Academic libraries may consider using Facebook to teach students how to do a research. On the other hand, using social media in an academic library is like dealing with a doubleedged knife which may have solutions as well as problems. Therefore it is better to have a guideline on using social media marketing for an academic library.

Library users serve as a very effective marketing force where a good word of mouth may spread and increase the positive image of the library. Library can use its passionate users to create promotional videos about the library and post it in Library Facebook/ Library webpage.

Marketing at academic libraries can be much more than promoting its products and services. Any kind of positive contact with students can be a meaningful interaction later on. Something as simple as free coffee at their examination period, when they are much stressed and mostly need that kindness may have an impact on user count and they will remember the interaction and more likely will reach the library for help. 
The library could organize exhibitions as a promotional marketing tool, to exhibit its unique historical rare collection, which includes books that are printed centuries earlier, materials that are found out of print, and books with historical value. By marketing its unique collection, the library could attract more users to the library.

\section{Reference}

Bennett, A. R. (1997). The five Vs - a buyer's perspective of the marketing mix. Marketing Intelligence \& Planning, 15(3), pp.151-156. Retrieved from https://doi.org/10.1108/02634509710165957

Dhiman, A. K. \& Sharma, H. (2009). Services Marketing Mix in Library and Information Centres. ICAL 2009 - Advocacy and Marketing, pp.456-460.

Garoufallou, E., Zafeiriou, G., Siatri, R., \& Balapanidou, E. (2013). Marketing applications in Greek academic library services. Library Management, 34(8/9), 632-649. https://doi.org/10.1108/LM-03-2012-0012

Garusing-Arachchige, J. (2002). Application of Marketing mix elements (4Ps) in the Library sector. Jula, 7(1), 12-36. Retrieved from http://eprints.rclis.org/6742/1/artjula.pdf

Jamaludin, A., Kadir, R. A., Hashim, D. M., Ahmad, M., \& Mansor, A. N. (2015). Impacts of Marketing Mix on the Usage of Library Services towards Library Users ' Satisfaction. Global Journal of Business and Social Science Review, 3(1), 73-78.

Krejcie, R. V, \& Morgan, D. W. (1970). Determining Sample Size for Research Activities, 607-610.Retrieved from http://journals.sagepub.com/doi/pdf/10.1177/001316447003000308

Perreault, W.D., Jr., \& McCarthy, E.J. (2002). Basic marketing: a global-managerial approach (14 ${ }^{\text {th }}$ Ed.). Boston: McGraw-Hill

Seddon, S. (1990). Marketing Library and Information Services. Library Management, 11(6), 35-39. Retrieved from https://doi.org/10.1081/EUM0000000000832

Vrana, R., \& Barbaric, A. (2007). Improving visibility of public libraries in the local community: A study of five public libraries in Zagreb, Croatia. New Library World, 108(9/10), pp.435-444. Retrieved from http://www.emeraldinsight.com/doi/pdfplus/10.1108/03074800710823962 